\title{
Educação em Perícia Contábil: Importância da Disciplina para o Curso de Contabilidade
}

\author{
João Luis Aguiar ${ }^{\text {; Daniel González González² }}$
}

\begin{abstract}
Resumo: A educação para futuros acadêmicos de contabilidade deve produzir profissionais com excelência contábil, de forma a dominarem certas habilidades, como: liderança, comunicação e conhecimentos da realidade que os envolve. Tais capacidades o habilitam a uma importante reflexão sobre a grande utilidade da Perícia Contábil, para que possam exigir cada vez mais, condições adequadas ao seu exercício profissional. O objetivo deste estudo foi comentar sobre a importância da perícia contábil enquanto disciplina nos cursos de contabilidade, bem como discorrer sobre alguns aspectos da mesma. Espera-se que este estudo aporte subsídios para que as universidades, possam compreender a importância social da disciplina Perícia Contábil e assim, possam ajudar a melhorar as condições de ensino dos cursos de contabilidade de uma maneira geral.
\end{abstract}

Palavras-chave: Contabilidade, Prova Pericial, Perícia contábil.

\section{Education in Accounting Expertise: Importance of Theme for the Accounting Course}

\begin{abstract}
Education for future accounting scholars should produce professionals with accounting excellence in order to master certain skills such as leadership, communication and knowledge of the reality that surrounds them. These capacities enable an important reflection on the great usefulness of Accounting Skills, so that they can increasingly demand, adequate conditions for their professional practice. The purpose of this study was to comment on the importance of accounting expertise as a discipline in accounting courses, as well as discuss some aspects of it. It is hoped that this study will contribute to enabling universities to understand the social importance of the Accounting Skills discipline and thus, to help improve the teaching conditions of accounting courses in general.
\end{abstract}

Keywords: Accounting, Expertise Testing, Accounting expertise.

\footnotetext{
${ }^{1}$ Pós Doutorando em Liderazgo para la Gestión e Innovación Educativa en una Sociedad Inclusiva; DOUTOR e MESTRE em GESTIÓN DE EMPRESAS pela UNIVERSIDAD AUTÓNOMA DE ASUNCIÓN - UAA. Pós-Graduado em Pericia Judicial; Controladoria e Finanças; Análise e Auditoria Contábil pela PUC-GO; Direito Tributário e Processo Tributário pela Atame/UCAM - Universidade Cândido Mendes (RJ); Bacharel em Ciências Contábeis pela UNIVERSO - Universidade Salgado de Oliveira. Atuou como professor internacional pela UNIVERSIDAD AUTÓNOMA DE ASUNCIÓN - UAA; FAFICH - Faculdade de Ciências Humanas de Goiatuba - GO e UNIFASC - Faculdade Santa Rita de Cássia de Itumbiara GO;

${ }^{2}$ Doctorado en Educación pela Universidad de Granada. Atualmente é Profesor Titular de Universidad da Universidad de Granada. Universidad Autónoma de Asunción e Universidad de Jaén (Espanha).
} 


\section{Introdução}

A Perícia Contábil é um meio de prova à disposição dos que dela necessitam, nas esferas judicial e extrajudicial (nesta incluído o juízo arbitral), para a solução de controvérsias de natureza técnica e científica sobre questões relativas ao patrimônio de pessoas e sociedades. É um serviço prestado pelo contador, na função de perito contábil, para auxiliar os tomadores de decisões: os juízes federais e estaduais e os membros dos tribunais arbitrais. A realização do exame pericial contábil requer elementos de prova obtidos no sistema contábil das entidades. Quanto mais organizada e atualizada a contabilidade, melhores serão os resultados do exame pericial.

A Perícia Contábil deve conter certos requisitos que constituem o conjunto de procedimentos técnicos e científicos destinados a levar à instância decisória elementos de prova aos que dela necessitam. Esses requisitos e procedimentos podem se materializar em dois relatórios: o laudo e o parecer pericial contábil, os quais devem observar as normas profissionais e a legislação específica no que for pertinente. O Perito Contábil deve ser tecnicamente qualificado, conhecer os aspectos legais, as normas contábeis de Perícia Contábil e dominar a matéria a ser analisada ou investigada. Esse cenário remete à discussão sobre a formação dos bacharéis em Ciências Contábeis.

A educação para futuros acadêmicos de contabilidade deve produzir profissionais com excelência contábil, de forma a dominarem certas habilidades, como: liderança, comunicação e conhecimentos da realidade que os envolve (MARION, 2001). Tais capacidades o habilitam a uma importante reflexão sobre a grande utilidade da Perícia Contábil, para que possam exigir cada vez mais, condições adequadas ao seu exercício profissional. "Os futuros contadores devem aprimorar-se no desenvolvimento das habilidades técnicas contábeis e, a frequência ao curso de graduação é parte da trajetória necessária a tal qualificação" (MARION, 2001, p.14).

A Resolução CNE/CES n. 10/2004 propõe, no seu artigo $4^{\circ}$, as condições mínimas para que um curso de Ciências Contábeis forneça uma adequada formação ao contador brasileiro, a saber: interdisciplinaridade, visão sistêmica, bem como uma correta aplicação da legislação vigente. 
Essa mesma Resolução propõe que o curso deve tornar o profissional de contábeis apto a interagir num contexto de mudanças, atual, adequando-se à realidade de uma sociedade globalizada. Portanto, é de esperar que os programas dos cursos de Ciências Contábeis busquem um alinhamento voltado à prática contábil cada vez mais contemporânea e de referencial bibliográfico atualizado.

O objetivo deste estudo foi comentar sobre a importância da perícia contábil enquanto disciplina nos cursos de contabilidade, bem como discorrer sobre alguns aspectos da mesma. Apresenta-se a seguir um panorama mais histórico e conceitual da perícia contábil, comentando aspectos mais básicos do fazer do contabilista.

\title{
Origem e História da Contabilidade
}

Alguns autores afirmam que a história da contabilidade é tão antiga quanto .+à própria história da civilização:

Segundo Iudícibus \& Marion (2000, p. 27).

\begin{abstract}
"Pode-se afirmar, com certa segurança, que a origem do campo de conhecimento do que mais tarde se consubstancia como Contabilidade (Accounting em inglês, Ragioneria em italiano) situa-se em torno de 4.000 anos a.C. Alguns historiadores fazem remontar a bem antes, por volta do sexto milênio a.C".
\end{abstract}

Dentro desta perspectiva, tem-se entre, outros, os trabalhos de:

a) Perez Jr. \& Begalli. (1999, p.14), afirmam:

\begin{abstract}
"Os mais velhos símbolos gráficos são os que Petrie encontrou nos vasos e pedras dos túmulos pré-históricos no Egito, da Espanha e do Oriente Próximo, aos quais ele dá idade de 7.000 anos. Esta Sinária Mediterrânea compunha-se de 300 sinais, em sua maioria os mesmos em todas as localidades, indicando obrigações comerciais de uma extremidade à outra do Mediterrâneo, por volta de 5.000 anos a.C. Não passavam de marcas mercantis de propriedades, de quantidades e outras".
\end{abstract}

b) Para Zanluca apud Aguiar (2008, pp. 28-29):

Há interessantes relatos bíblicos sobre controles contábeis, um dos quais o próprio Jesus relatou em Lucas capítulo 16, versículos 1 a 7: o administrador que fraudou seu senhor, alterando os registros de valores a receber dos devedores. Já no tempo de José, no Egito, houve tal acumulação de bens que perderam a conta do que se tinha! (Gênesis 41.49). 
Houve um homem muito rico, de nome Jó, cujo patrimônio foi detalhadamente inventariado no livro de Jó, capítulo 1, verso 3. Depois de perder tudo, ele recupera os bens, e um novo inventário é apresentado em Jó, capítulo 42, verso 12. Os bens e as rendas de Salomão também foram inventariados em $1^{\circ}$ Reis 4.22-26 e 10.14-17.

Em outra parábola de Jesus, há citação de um construtor, que faz contas para verificar se o que dispunha era suficiente para construir uma torre (Lucas 14.28-30). Ainda, se relata a história de um devedor, que foi perdoado de sua dívida registrada (Mateus 18.23-27). Tais relatos comprovam que, nos tempos bíblicos, o controle de ativos era prática comum.

c) Segundo, Santos, Schmidt \& Gomes (2006, p.11):

\begin{abstract}
"No Brasil, existe grande preocupação, por parte dos legisladores, com a qualidade da informação contábil decorrente da mudança no cenário econômico mundial. Prova disso são as constantes alterações da Lei das Sociedades por Ações em seu escopo pelo processo de globalização da economia".
\end{abstract}

Portanto, entende-se que a evolução da contabilidade é tão antiga quanto à própria humanidade e está evoluindo cada vez mais com a evolução da humanidade neste mundo globalizado e, assim, surgiram vários seguimentos dentro da contabilidade como a Contabilidade Industrial, Contabilidade Bancária, Contabilidade Comercial, Auditoria Contábil, bem como a busca da prova pericial contábil, através da Perícia Contábil, a qual é uma investigação contábil de empresas e pessoas físicas motivadas por uma questão judicial, quando solicitado pela justiça.

Nesse entendimento, segundo Silva, L. G. C. (1994, p.22) apud Zanna (2011, p. 23):

“As principais especializações da Contabilidade são: a) Controle Contábil; b) Contabilidade de Custos; c) Contabilidade Gestorial; d) Análise de Balanços; e) Auditoria; f) "Perícia Contábil". "(o grifo é nosso)".

\title{
Visão geral da perícia
}

A perícia contábil teve seu surgimento em épocas remotas, ou seja, é tão antiga quando a contabilidade que foi se evoluindo com as crescentes mudanças econômicas e a evolução da humanidade, apesar disso, conforme, menciona Santana (1999, p.2) apud Montandon (2006, p.2), 
“[...] somente no Século XIX, por intermédio das Ordenações Filipinas, que o procedimento atualmente vigente para realização de perícias foi estabelecido no direito português e, por consequência, na legislação brasileira".

$\mathrm{O}$ quadro $\mathrm{n}^{\mathrm{o}} 1$, que se segue, busca sintetizar a cronologia histórica da evolução da perícia contábil:

Quadro no 1: Cronologia Histórica da Perícia

\begin{tabular}{|c|c|}
\hline Período & Principais Acontecimentos \\
\hline Ano 4.000 a.C. & $\begin{array}{l}\text { Primeiros sinais do uso da contabilidade e primeiros vestígios de perícias } \\
\text { para agrimensura. }\end{array}$ \\
\hline Ano 1.248 a.C. & $\begin{array}{l}\text { Claras referências da realização de perícias de levantamento de locais de } \\
\text { morte violenta na obra Si Yuan Lu, do juiz Song Ts'Eu, na China. }\end{array}$ \\
\hline Ano 130 d.C. & $\begin{array}{l}\text { Vestígios de escritas de perícia no papiro Abbot, ao tempo do Imperador } \\
\text { Adriano Trajano Augusto. Corresponde a um autêntico laudo do médico } \\
\text { Caio Minucio Valeriano, do burgo de Caranis, a propósito de ferimentos } \\
\text { na cabeça recebidos por um indivíduo chamado Mysthorion. }\end{array}$ \\
\hline Século VIII & $\begin{array}{l}\text { O Imperador Carlos Magno, nas Leis capitulares, Sálicas e Germânicas, } \\
\text { exigia a interferência de médicos para analisar ocorrências de mortes } \\
\text { violentas. }\end{array}$ \\
\hline A partir do século XIII & $\begin{array}{l}\text { Grande desenvolvimento da perícia como instrumento de prova na Grécia, } \\
\text { França, Inglaterra e Itália. }\end{array}$ \\
\hline Século XIV & $\begin{array}{l}\text { O papa Gregório XI, nas Leis Decretais, determinava a realização de } \\
\text { perícias médicas para a comprovação de casos de impotência, aborto e } \\
\text { lesões corporais. }\end{array}$ \\
\hline No ano de 1850 & $\begin{array}{l}\text { A perícia surge regulamentada no Brasil pela Lei número } 556 \text { de } 25 \text { de } \\
\text { junho de } 1850 \text { - Código Comercial - que estabeleceu o Juízo Arbitral } \\
\text { obrigatório nos casos de abalroação de navios. } \\
\text { Regulamento número } 737 \text { de } 25 \text { de dezembro de } 1850 \text {, sobre o } \\
\text { funcionamento do perito. Em matéria contábil, é escolhido o profissional } \\
\text { formado em aula de Comércio com posse da Carta de Habilitação. }\end{array}$ \\
\hline No ano de 1863 & $\begin{array}{l}\text { Pela primeira vez é utilizada a arbitragem na chamada 'Questão Christie', } \\
\text { caso que envolvia a detenção de oficiais da marinha britânica por } \\
\text { autoridades policiais brasileiras. A arbitragem, cujo laudo foi favorável ao } \\
\text { Brasil, foi feita pelo Rei Leopoldo, da Bélgica. }\end{array}$ \\
\hline No ano de 1866 & $\begin{array}{l}\text { Revogado o Juízo arbitral obrigatório pela Lei número } 1.350 \text { (o juízo } \\
\text { arbitral voluntário permaneceu). }\end{array}$ \\
\hline No ano de 1911 & $\begin{array}{l}\text { O governo brasileiro decreta lei sobre peritos contabilistas, estabelecendo } \\
\text { suas atribuições. }\end{array}$ \\
\hline No ano de 1916 & $\begin{array}{l}\text { Em } 20 \text { de setembro de } 1916 \text { é aprovado o regulamento pronunciando-se } \\
\text { sobre a perícia contábil. }\end{array}$ \\
\hline No ano de 1917 & $\begin{array}{l}\text { Entra em vigor a Lei número } 3.071 \text {, de } 1^{\circ} \text { de janeiro de } 1916 \text { - Código } \\
\text { Civil. Que tem entrado a profissão do contador e consequentemente, a } \\
\text { perícia contábil. }\end{array}$ \\
\hline No ano de 1939 & $\begin{array}{l}\text { Entra em vigor o Decreto Lei número } 1.608 \text {, de } 18 \text { de setembro de } 1939 \text {. } \\
\text { Definia a participação do perito nas ações judiciais, mais precisamente no } \\
\text { campo do direito civil e comercial. }\end{array}$ \\
\hline No ano de 1946 & $\begin{array}{l}\text { Entra em vigor o Decreto Lei número } 9.295 \text { de } 27 \text { de maio de } 1946 \text {, que } \\
\text { define as atribuições do Contador e do Guarda-livros a legalização da } \\
\text { perícia contábil. }\end{array}$ \\
\hline No ano de 1973 & $\begin{array}{l}\text { Entra em vigor o Novo Código de Processo Civil, lei número } 7.270 \text { de } 10 \\
\text { de dezembro de } 1984 \text {. Estabeleceu-se que o perito necessitava de formação } \\
\text { universitária. }\end{array}$ \\
\hline No final do ano de 2009 & $\begin{array}{l}\text { O Conselho Federal de Contabilidade aprova as Resoluções CFC } \mathrm{n}^{\circ} \\
\text { 1.243/09, que aprova a NBC TP 01- Perícia Contábil e a Resolução CFC } \\
\mathrm{n}^{\mathrm{o}} 1.244 / 09 \text {, que aprova a NBC PP } 01 \text { - Perito Contábil. }\end{array}$ \\
\hline
\end{tabular}

Fonte: Adaptado de Santana (1999) e Zarzuela et al. (2000) apud Montadon, (2006, p.7). 
Nesse sentido, o Decreto-Lei $\mathrm{n}^{\circ}$ 9.295/46, de 27 de maio de 1946, em seu art. 25, alínea "c", atribui:

“[...] perícias judiciais ou extrajudiciais, revisão de balanços e de contas em geral, verificação de haveres, revisão permanente ou periódica de escritas, regulações judiciais ou extrajudiciais de avarias grossas ou comuns, assistência aos Conselhos Fiscais das sociedades anônimas e quaisquer outras atribuições de natureza conferidas por lei aos profissionais de contabilidade."

Sobre as prerrogativas profissionais de que trata esse artigo, foi regulamentado pela Resolução do CFC n ${ }^{\circ}$ 560/83, que determina em seu artigo $3^{\circ}$, item 35, “(Art. $3^{\circ}$ São atribuições privativas dos profissionais da contabilidade: 35) perícias contábeis, judiciais e extrajudiciais".

O profissional Contador, para o cumprimento da função de perito contábil, necessita possui curso superior, Bacharel em Ciências Contábeis, estar regulamentado junto ao seu órgão de classe, ou seja, registrado no Conselho Regional de Contabilidade do estado em que atua; possuir um vasto conhecimento na matéria a ser periciada, educação continuada, compreender a relação entre a doutrina jurídica e a doutrina contábil nos aspectos que disciplinam sua presença no procedimento processual e, possivelmente, uma Pós-graduação em pericial judicial.

Conforme menciona Pires (2005, p. 11):

\begin{abstract}
"A utilização da ciência contábil para a formação da prova pericial exige do profissional nomeado pelo magistrado a plena consciência de seu dever legal e da percepção de que o laudo produzido necessita apresentar atributos que demonstram a qualidade do trabalho e evidencie o cumprimento das normas contábeis que disciplinam o exercício da função pericial."
\end{abstract}

Nesse entendimento, é fundamental que os trabalhos periciais importam sempre em exame que sejam realizados por técnicos, isto é, por peritos ou pessoas hábeis e conhecedoras da matéria a ser periciada.

\title{
Conceito de Perícias
}

Assim, pelo conceito etimológico da palavra, pode-se inferir que a perícia é uma habilidade que vai se adquirindo no decorrer da vida, através do saber e dos trabalhos realizados, ou seja, a perícia consiste numa declaração de ciência sobre fatos relevantes à

241 Id on Line Rev. Mult. Psic. V.13, N. 45 SUPLEMENTO 1, p. 236-257, 2019 - ISSN 1981-1179 Edição eletrônica em http://idonline.emnuvens.com.br/id 
causa, emitida por pessoa com relevante sabedoria, também chamada de expert, com o objetivo de esclarecer aspectos técnicos, mediante exame, vistoria, indagação, investigação, arbitramento, avaliação, com objetivo de exclusivo de fazer prova perante o Magistrado e as partes envolvidas na discussão.

Etimologicamente, na conceituação de Morais \& França, (2000, p.29), “a palavra perícia vem do latim peritia, que significa (habilidade, saber, conhecimento), que, na linguagem jurídica, designa, no seu senso lato, diligência realizada por perito, a fim de se evidenciar determinados fatos".

Do mesmo modo e com maior abrangência, partindo do conceito etimológico do vocabulário, Serres apud Morais \& França (2000, pp.29-30), que se segue:

\begin{abstract}
“[...] la respuesta oral o escrita que esos especialistas proporcionan al juez de la causa en las cuestiones que se les someten a su resolución; el informe razonado que ellos emiten sobre algún punto planeado en el expediente, se llama dictamen y también pericia, vocablo este último que proviene del latín "peritia", el que significa sabiduría, práctica, experiencia y habilidad en una ciencia o arte".
\end{abstract}

Alberto, (2002, p. 19), conceitua perícia como “[...] instrumento especial de constatação, prova ou demonstração, científica ou técnica, da veracidade de situações, coisas ou fatos".

Já na conceituação de Moura (2010, p. 5), “a perícia designa a diligência realizada ou executada por peritos, a fim de que se apurem, esclareçam ou se evidenciem certos fatos".

Pode-se conceber a perícia em várias áreas do conhecimento, como administrativa, financeiras, cível, criminal, trabalhista previdenciária e outras. Na cível, por exemplo, a perícia encontra-se regulamentada no Código de Processo Civil - CPC, Lei $n^{\circ}$ 5.869/73, que embora, não seja esclarecedora quanto aos procedimentos profissionais. Como no artigo 145, o mencionado CPC determina que a perícia deva ser executada por profissional de nível universitário, devidamente registrado no órgão de classe da sua profissão.

No entendimento de Santos, J.L; Schidt, P. \& Gomes, J. M. M. (2006, p.17), elucidam a perícia como:

\footnotetext{
"Perícia é a diligência efetuada por perito, a fim de esclarecer ou evidenciar fatos que envolvem necessariamente o saber do especialista, do técnico habilitado profissionalmente, nunca esquecendo que cada ciência aprecia os diferentes fenômenos em conformidade com seus próprios princípios e normas.”
} 


\title{
Conceito de Perícia Contábil
}

Podemos perceber que até aqui, buscou-se um conceito de forma genérica do que é perícia, a qual possui um campo extenso a ser pesquisado. Nesse entendimento pode-se dizer que o campo de atuação da perícia está relacionado a todas as situações contraditórias e de desequilíbrio que envolver uma discussão na sociedade.

O conceito de perícia contábil está diretamente ligado ao conceito genérico da perícia no que se refere à habilidade, o saber, a perspicácia na busca da prova pericial, visto que a matéria pericial recairá, em área do conhecimento humano o qual irá atuar, como na medicina, administração, finanças, engenharia, informática, e no nosso estudo, é o reflexo da prova pericial na área da ciência contábil, através de estudo de casos, portanto, neste momento há a necessidade de esclarecer o que é a ciência contábil.

De acordo com Marion, (2009, p. 28) o conceito de contabilidade é o que se segue:

\begin{abstract}
“A Contabilidade é o instrumento que fornece o máximo de informações úteis para a tomada de decisões dentro e fora da empresa. [...] todas as movimentações possíveis de mensuração monetária são registradas pela contabilidade, que, em seguida, resume os dados registrados em forma de relatórios e os entrega aos interessados em conhecer a situação da empresa. Esses interessados, através de relatórios contábeis, recordam os fatos acontecidos, analisam os resultados obtidos, as causas que levaram àqueles resultados e tomam decisões em relação ao futuro."
\end{abstract}

Segundo entendimento do El Comité sobre Terminología del AICPA de los EE.UU., propuso em 1941, apud Pavón (2004, p.21), "El arte de registrar, classificar y resumir de uma manera siginificativa y em términos monetários las transaciones y eventos que son, cuando menos em parte, de caráter financeiro, así como de interpretar sus resultados"

Crepaldi (2004, p. 21), “afirma que o grande objetivo da contabilidade é planejar e colocar em prática um sistema de informação para uma organização, com ou sem fins lucrativos".

Ainda de acordo com Crepaldi (2002, p. 18) apud Montandon (2006, p.12), apresenta duas definições de contabilidade:

"É a ciência concebida para coleta, registrar, resumir e interpretar dados e fenômenos que afetam as situações patrimoniais, financeiras e econômicas de qualquer entidade", e o "método econômico-administrativo de apuração do resultado da gestão da azienda e do controle de seu patrimônio". 
Nesse entendimento pode se dizer que a Contabilidade é o grande instrumento que auxilia a administração a tomar decisões. Na verdade, ela coleta todos os dados econômicos, mensurando-os em forma de relatórios ou de comunicados, que contribuem sobremaneira para a tomada de decisões para quem a utiliza.

Portanto, o objeto da contabilidade é patrimônio das entidades com ou sem fins lucrativos, econômico-administrativo e financeiro, que a contabilidade estuda e coleta os dados, processa e repassa aos seus usuários para análise, controle e tomada de decisões úteis dentro e fora dessas entidades.

Assim, a busca da prova pericial contábil está ligada diretamente a verificação de fatos ligados ao patrimônio individualizado das empresas e pessoas, visando oferecer opinião técnica, mediante as questões em proposta.

O Conselho Federal de Contabilidade, por sua vez, conceitua a perícia contábil pela Resolução CFC n 1.243/09, que aprova a NBC TP 01 - Perícia Contábil, da seguinte forma (item 2):

\begin{abstract}
"A perícia contábil constitui o conjunto de procedimentos técnico-científicos destinados a levar à instância decisória elementos de prova necessários a subsidiar à justa solução do litígio ou constatação de um fato, mediante laudo pericial contábil e/ou parecer pericial contábil, em conformidade com as normas jurídicas e profissionais, e a legislação específica no que for pertinente".
\end{abstract}

Moura (2002, p.1) apud Montandon (2006, p.13), no mesmo entendimento, também, enfoca os aspectos práticos conceituando a perícia contábil como:

\footnotetext{
"Perícia contábil é a apuração, através de procedimentos técnicos diversos, visando esclarecer dúvidas, efetuar cálculos de partilhas entre sócios, reavaliações patrimoniais, cálculo de ágio ou deságio de ações, apurações do valor do patrimônio líquido, apurações de fundo de comércio, além de outros, e o oferecimento de elementos elucidativos para o deslinde de controvérsias".
}

Para Sá, (2005, p.14), a perícia contábil tem uma abrangência mais completa, ou seja, envolvem todos os procedimentos possíveis para se formar uma opinião, conforme segue, "Perícia contábil é a verificação de fatos ligados ao patrimônio individualizado visando oferecer opinião, mediante questão proposta. Para tal opinião realizam-se exames, vistorias, indagações, investigações, avaliações, arbitramentos, em suam todo e qualquer procedimento necessário à opinião". 
Para Gonçalves, (1968:152) apud Morais (2005, p. 42), "Perícia Contábil é, pois, o exame hábil (...) com objetivo de resolver questões contábeis, ordinariamente originárias de controvérsias, dúvidas e de casos específicos determinados ou previstos em lei”.

Segundo D’Auria, (1968:7) apud Morais (2005, p. 42), perícia judicial “[...] é o testemunho de uma ou mais pessoas técnicas (experts), no sentido de fazer conhecer um fato cuja existência não pode ser acertada ou juridicamente apreciada, senão apoiada em especiais conhecimentos científicos ou técnicos".

Portanto, partindo de tais conceitos é que a perícia contábil tornou-se de extrema importância para os processos judicial, semijudicial, arbitral e extrajudicial e, em vários casos, imprescindível, pois possibilita ao julgador proferir decisões justas, especialmente nas causas de prestações de contas, de apuração de haveres, de avaliação do acervo patrimonial, em revisão de contratos e renegociação de dívidas, crimes financeiros e lavagem de dinheiro, indenização e outras.

\section{Objetivos da Perícia Contábil}

Pelo que já se buscou, entende-se que o objetivo precípuo de da perícia contábil é de restabelecer e restaurar a paz social através de um processo dialético, isto é, mostrando a verdade de um fato a uma ou mais pessoas que a busquem, o que se materializada através do laudo pericial contábil.

No entendimento de Jesus, (2000, p. 1), o objetivo da prova pericial é:

\footnotetext{
"A forma objetiva de conhecermos a verdade de um fato, a veracidade de um feito ou a real percepção de um objeto ou coisa examinada. E considerando-se sob esse aspecto, é o meio de demonstrar nos autos, por documentos, peças ou declarações de testemunhas, tudo que se colheu nos exames efetuados, procurando-se transportar a verdade dos fatos para os autos. Esta verdade é concordância existente entre um fato real e a idéia da representação mental, presente em nosso cérebro".
}

Assim, o objetivo maior da perícia contábil é a verdade sobre o objeto examinado, melhor dizendo, o objetivo maior é a transferência da verdade contábil para o ordenamento o processo ou outra forma da instância decisória. 
O campo e as situações em que é possível a perícia contábil é um objetivo difícil de ser alcançado, a não ser que tomemos o caminho das exemplificações, pois as situações que a perícia pode atuar são inumeráveis, podendo os objetivos específicos de uma perícia contábil assumir variadas formas. Nesse entendimento é importante informar esses objetivos em situações reais, conforme exemplificação real no Quadro 2, que se segue:

Quadro 2: Objetivos periciais e situações reais

\begin{tabular}{|c|c|c|}
\hline Itens & Objetivos & Exemplo de objetivo \\
\hline 1 & A informação fidedigna. & $\begin{array}{l}\text { Apuração das vendas efetivas de produtos sujeitos } \\
\text { contratualmente a pagamento de royalties. }\end{array}$ \\
\hline 2 & $\begin{array}{l}\text { A certificação, o exame e a } \\
\text { análise do } \begin{array}{l}\text { estado } \\
\text { circunstancial. }\end{array}\end{array}$ & $\begin{array}{l}\text { Verificar da contabilização nos livros do credor e do } \\
\text { devedor das operações que deram origem à duplicata } \\
\text { questionada em juízo. }\end{array}$ \\
\hline 3 & $\begin{array}{l}\text { O esclarecimento e a } \\
\text { eliminação das dúvidas } \\
\text { suscitadas sobre o objeto. }\end{array}$ & $\begin{array}{l}\text { Analisar a origem, forma de integralização e quantidade } \\
\text { das ações negociadas em Bolsa de Valores que } \\
\text { proporcionaram a transferência de controle acionário } \\
\text { questionada. }\end{array}$ \\
\hline 4 & $\begin{array}{l}\text { O fundamento científico da } \\
\text { decisão. }\end{array}$ & $\begin{array}{l}\text { Emitir parecer sobre as atividades empresariais do ponto } \\
\text { de vista doutrinário da Ciência Contábil para fins de } \\
\text { distinção entre aquelas sujeitas ao Imposto sobre } \\
\text { Serviços. }\end{array}$ \\
\hline 5 & $\begin{array}{l}\text { A formulação de uma } \\
\text { opinião ou juízo técnicos. }\end{array}$ & $\begin{array}{l}\text { Emitir parecer conclusivo sobre a correção ou não da } \\
\text { prestação de contas da diretoria ou administrador da } \\
\text { entidade. }\end{array}$ \\
\hline 6 & $\begin{array}{l}\text { A mensuração, a analise, a } \\
\text { avaliação ou arbitramento } \\
\text { sobre o quantum monetário } \\
\text { objeto. }\end{array}$ & $\begin{array}{l}\text { Apurar o valor correto dos haveres do autor constantes } \\
\text { ou que deveriam constar do acervo patrimonial da } \\
\text { entidade examinada. }\end{array}$ \\
\hline 7 & $\begin{array}{l}\text { Trazer à luz o que está } \\
\text { oculto por inexatidão, erro, } \\
\text { inverdade, má-fé, astúcia ou } \\
\text { fraude. }\end{array}$ & $\begin{array}{l}\text { Investigar contabilmente a existência ou inexistência de } \\
\text { atos lesivos ou que visem a fraudar o interesse de } \\
\text { credores de uma empresa concordatária ou falida. }\end{array}$ \\
\hline
\end{tabular}

Fonte: adaptado de Alberto (2002, p.52).

\section{A Prova Pericial Contábil}

É a verdade que busca, que na opinião profissional, deflui de um conhecimento específico, tem responsabilidades relevantes como elementos que visa a oferecer a prova.

A prova pericial encontra-se regulada pelo Código de Processo Civil (CPC), sendo considerada, por todos aqueles que lidam no mundo jurídico de elevada relevância. 
Hoog (2008, p. 99) afirma que "a prova pericial é regulada pelo art. 332 do CPC, onde todos os meios legais, bem como os moralmente legítimos são hábeis para confirmar os fatos alegados na inicial ou na contestação".

Ainda, em conformidade com o art. 332 do CPC, "Todos os meios legais, bem como os moralmente legítimos, ainda que não especificados neste Código, são hábeis para provar a verdade dos fatos, em que se funda a ação ou a defesa”. Dessa maneira, incumbe ao litigante em Juízo para sair vitorioso em convencer o nobre Magistrado, por meio da prova, que está com a razão.

É importante que a prova pericial contábil, seja solicitada pelas partes na petição inicial, que segundo o art. 276, explicita: "Na petição inicial, o autor apresentará o rol de testemunhas e, se requerer perícia, formulará quesitos, podendo indicar assistente técnico. (Redação dada pela Lei n ${ }^{\circ}$ 9.245, de 1995)".

Portanto, a solicitação da prova segue a intenção das partes ou obrigação conforme prevê o direito objetivo, que são os meios idôneos e legais para formar a convicção do ilustre julgador.

Normalmente, um dos litigantes pode pedir a sua dispensa quando juntar nos autos um parecer contábil hábil e não tendencioso para auxiliar a convicção do preclaro julgador, quando o fato que se pretende provar é notório.

Assim, cabendo a sua dispensa conforme artigo 427 do CPC ou indeferimento com fundamento nos artigos 130 e 420 do mesmo código. Caso não seja, assim, o entendimento do magistrado e havendo a necessidade de realizar uma perícia é nomeado um profissional de sua estrita confiança para a busca da prova pericial contábil, cabendo às partes a indicação de assistente técnico.

Quando a dispensa da prova, vejamos o artigo 427 do CPC, “Art. 427. O juiz poderá dispensar prova pericial quando as partes, na inicial e na contestação, apresentarem sobre as questões de fato pareceres técnicos ou documentos elucidativos que considerar suficientes. (Redação dada pela Lei no 8.455, de 1992)”.

Esta dispensa da prova pericial, naturalmente é de ordem subjetiva e depende do convencimento do magistrado, tendo vários reflexos, sendo o mais relevante o cerceamento de defesa, no sentido de que todos os meios são possíveis para provar a verdade em discussão. A sua dispensa, porém, é possível, a legislação assim prevê. 
No que se refere ao indeferimento, vejamos o que diz o artigo 130 do CPC, “Art. 130. Caberá ao juiz, de ofício ou a requerimento da parte, determinar as provas necessárias à instrução do processo, indeferindo as diligências inúteis ou meramente protelatórias".

Constam ainda no parágrafo único do art. 420 do CPC sobre a prova pericial, “parágrafo único. O juiz indeferirá a perícia quando: I - a prova do fato não depender do conhecimento especial de técnico; II - for desnecessária em vista de outras provas produzidas; III - a verificação for impraticável”.

Somente o juiz pode indeferir uma diligência, como, por exemplo, a verificação de uma escritura contábil. Ao perito cabe responder aos pontos não indeferidos e efetuar as diligências para a busca da prova pericial contábeis.

É assim, que o juiz indeferirá até a inquirição de testemunhas, se os fatos só puderem ser provados por exame pericial, conforme estabelece o art. 400 do CPC:

Art. 400. A prova testemunhal é sempre admissível, não dispondo a lei de modo diverso. O juiz indeferirá a inquirição de testemunhas sobre fatos:

I - já provados por documento ou confissão da parte;

II - que só por documento ou por exame pericial puderem ser provados.

Embora seja valiosa, sua admissão nem sempre ocorre, devendo restringir-se às lides em que realmente seja imprescindível sua realização.

De acordo com a vivência profissional, é do entendimento que a prova pericial contábil é uma das mais relevantes, pois o perito contábil possui o conhecimento científico e técnico, conclusão esta que está disciplinada no art. 145 do CPC, "Quando a prova do fato depender de conhecimento técnico ou científico, o juiz será assistido por perito [...]”. Nesse entendimento, o perito ilumina o Julgador, e os resultados contábil e científico capacitam o Magistrado na sua justa decisão.

Morais \& França (2004, p.121) relatam que:

\footnotetext{
"A prova pericial muitas vezes se confunde com a própria perícia, embora a primeira seja a verdade dos fatos e a segunda vise à busca dessa verdade. O perito, profissional especializado na busca da verdade, tem como objetivo de trabalho encontrar a prova. Sem prova à perícia não obtém êxito e, consequentemente, não contribui com a justiça e nem com a sociedade".
} 
Paixão Júnior (2002) apud Pires (2005, p. 38) "relata que meios de prova são os veículos disponibilizados pela lei às partes, a fim de que possam exercer o direito probatório. A perícia contábil, como qualquer das provas, é uma das admitidas em Direito".

Alberto (2002, p. 122) escreve que: "toda a técnica pericial pressupõe o emprego da metodologia científica, já que perícia só é perícia se houver o emprego de conhecimentos técnicos ou científicos".

Palma (2002) apud Pires (2005, p. 38) reforça que "a prova pericial como atividade de pesquisa técnica ou científica integrada pelas etapas de verificação, constatação e análise do objeto em questão, a ser efetivada por agente formal ou especialista na matéria a ser pesquisada".

Jesus (2000, p. 4) "na busca da verdade dos fatos, o juiz se instrui, em outras, com a prova pericial, para, mediante convicção nela fundamentada, realizar justo pronunciamento, atribuído a cada um o que por direito é seu".

Segundo Goni (1995) apud Jesus (2000 p. 4) "logo, a perícia constitui um elemento fundamental para a convicção do magistrado sobre a espécie submetida ao seu juízo".

A prova pericial se estrutura e materializa no laudo pericial contábil. A identificação dos atributos essenciais que demonstrem de forma, rigor tecnológico, consistência das conclusões e atendimento do objeto pelo qual foi reclamado, em sua extensão, complexidade e profundidade, está exposto no próximo subcapítulo.

\section{Laudo Pericial Contábil}

O perito nomeado do Juiz apresenta suas conclusões em uma peça técnica, estruturada de forma a demonstrar conhecimento da lide em discussão em seus fatos, identificar o objeto da perícia e a evidenciar as arguições, as contra arguições e, assim, formando a sua opinião técnica.

O laudo pericial contábil está normatizado pela Resolução CFC n ${ }^{\circ} 1.243 / 09$, que aprova a NBC TP 01 - Perícia Contábil, em vigor a partir do dia $1^{\circ}$ de janeiro de 2010, que disciplina sobre a elaboração do laudo e do parecer pericial contábil, conforme consta no seu item "57": 
“O Decreto-Lei no 9.295/46, na alínea “c” do art. 25, determina que o laudo pericial contábil e o parecer pericial contábil somente sejam elaborados por contador que esteja devidamente registrado e habilitado em Conselho Regional de Contabilidade”.

Entende-se por laudo pericial contábil a peça escrita por um profissional, devidamente, registrada no Conselho Federal de Contabilidade (CFC), através do Conselho Regional de Contabilidade (CRC) no Estado em que atua na categoria de Contador, isto é, com curso superior denominado de Bacharel em Ciências Contábeis, que visa expressar uma opinião técnica acerca da matéria ora periciada para dirimir controvérsia a respeito da matéria que envolve o patrimônio (bens, direitos e obrigações), objeto de estudo da Contabilidade.

Moura (2007, p. 26) conceituou laudo pericial contábil, como:

"[...] uma peça escrita, na qual o perito deve visualizar, de forma abrangente, o conteúdo da perícia e particularizar os aspectos e as minudências que envolvam a demanda, a lide, o litígio, e deve ser elaborado de forma sequencial e lógica, para que o trabalho do perito seja reconhecido também pela padronização estrutural”.

Fiker (2005, p.49), menciona sobre a produção do laudo:

\begin{abstract}
"Todo discurso, quer seja religioso político, científico ou de outra natureza, tem uma estrutura que é seguida, [...] pode ser dito que lhe confere um princípio, um meio e um fim, com o objetivo de estruturá-lo e evitar repetições desnecessárias daquilo de que já havia sido dito, bem como concatenar suas partes no sentido de que seja mais objetivo, aumentando sua capacidade de persuasão e tornando-o menos cansativo e mais atraente para o destinatário".
\end{abstract}

No entendimento de Rocha \& Santos (2004, p. 42) "feitas às diligências e anotações necessárias; apurados os dados, documentos e provas; elaboradas as demonstrações, memórias de cálculos ou planilhas, é o momento de escrever o laudo".

Segundo Sá (2005, p. 43), "laudo é uma palavra que provém da expressão verbal latina substantivada laudare (laudo, laudare), no sentido de "pronunciar", tal como a empregou [...]. É o julgamento ou pronunciamento, baseado nos conhecimentos que tem o profissional da contabilidade, em face de eventos ou fatos que são submetidos a sua apreciação".

Outras conceituações apresentados tem contribuído para se conhecer o conceito do que é laudo pericial contábil. Santos, Schmidt \& Gomes (2006, p. 65) “o laudo pericial consiste na exposição das operações e ocorrências da diligência, com o parecer fundamentado sobre a matéria que lhes foi submetida". 
Hoog (2011, p. 70) “os laudos periciais contábeis são relatos executados por perito qualificado e habilitado na forma definida no Código de Processo Civil. A habilitação para a perícia contábil judicial deve ser comprovada por certidão expedida pelo CRC, por força do art. $145, \S 2^{\circ}$, do CPC".

Alberto (2002, p. 123) “[...] é a manifestação da realidade concreta de todo o esforço perquiritório, investigativo e intelectual do profissional".

Ainda Hoog (2008, p.191), conceitua laudo pericial como: "[...] é a peça probante escrita, objetiva, clara, precisa e concisa na qual o perito contador expõe, de forma circunstanciada, as observações e estudos que fizeram e registram as conclusões fundamentadas da perícia".

Na concepção de Zarzuela (2000), apud Pires (2008, p. 63),

\begin{abstract}
"O laudo pericial consiste na exposição minuciosa, circunstanciada, fundamentada e ordenada das apreciações e interpretações realizadas pelo perito, com a pormenorizada enumeração e caracterização dos elementos de prova destinada a levar a juiz elementos instrutórios de ordem técnica, podendo consistir em uma declaração de ciência ou em uma afirmação de um juízo, ou em ambas as operações, simultaneamente".
\end{abstract}

Assim, a busca da verdade em relação aos fatos que exigem a prova pericial contábil é um dos fundamentos que se devem priorizar no trabalho, dado que o maior dever do auxiliar do juízo é materializá-la por meios de documentos insertos nos autos ou arrecadados mediante diligências, mas que no final sirvam para o fortalecimento da prova, pois a pesquisa e a investigação são atributos fundamentais de sustentação da perícia. Sem elas o perito não conseguirá defender seu laudo nem oferecer a prova esperada para auxiliar a sentença judicial.

O Código de Processo Civil não define o que é laudo pericial e também não proporciona conhecimento à sua feitura. Deixou aos peritos a livre escolha para que possam dimensioná-lo da forma que bem entenderem; e o que, geralmente, se vê é uma grande quantidade de tipos e formas de laudos, cada um direcionando, muitas vezes, para os interesses de cada um, para as profissões de cada perito e, em muitos casos, deixando de serem peças de agradável leitura e compreensão.

Assim se refere o Código de Processo Civil sobre o assunto mencionado; "Art. 421. O juiz nomeará o perito, fixando de imediato o prazo para a entrega do laudo. (Redação dada pela Lei $n^{\circ} 8.455$, de 1992)”.

251 Id on Line Rev. Mult. Psic. V.13, N. 45 SUPLEMENTO 1, p. 236-257, 2019 - ISSN 1981-1179 Edição eletrônica em http://idonline.emnuvens.com.br/id 
Entende-se que o laudo pericial contábil é um documento que precisa ser direcionado em conformidade com o seu objeto, com conteúdo claro e preciso dos fatos em discussão, sob pena de perder a sua credibilidade. O juiz não está obrigado a aceitar o laudo se não contiver provas e evidências irrefutáveis, podendo adotar como provas outros documentos juntados aos autos, ou seja, outras provas que surgirem mais robustas que o laudo pericial.

Por fim, o laudo pericial contábil deve conter uma estrutura mínima para a sua elaboração e apresentação aos autos do processo em litígio.

\title{
Estrutura do Laudo Pericial Contábil
}

Conforme escreve Alberto (2002, p. 124) o laudo deve conter:

\begin{abstract}
"[...] se possível nesta ordem, o seguinte: (a) Abertura (o Parágrafo introdutório dos hispânicos); (b) Considerações iniciais a respeito das circunstâncias de determinação judicial ou consulta, vem como os exames preliminares da perícia contábil; (c) Determinação e descrição do objeto e dos objetivos da perícia; (d) Informação da necessidade ou não de diligências e, quando houver, a descrição dos atos e acontecimentos dos trabalhos de campo; (e) Exposição dos critérios, exames e métodos empregados no trabalho; (f) Considerações finais onde conste a síntese conclusiva do perito a respeito da matéria analisada; (g) Transcrição e respostas aos quesitos formulados; (h) Encerramento do laudo (ou parágrafo final), com identificação e assinatura do profissional, e (i) quando houver, a juntada sequencia, dos Anexos, documentos ou outras peças abojadas ao laudo e ilustrativas deste".
\end{abstract}

Sugere o Conselho Federal de Contabilidade (2009), pela Resolução no 1.243 de 10 de dezembro de 2009, que aprovou a NBC TP 01 - Perícia Contábil, no item 80, o laudo pericial contábil deve conter, no mínimo os seguintes itens:

(a) Identificação do processo e das partes;

(b) Síntese do objeto da perícia;

(c) Metodologia adotada para os trabalhos periciais;

(d) Identificação das diligências realizadas;

(e) Transcrição e resposta aos quesitos: para o laudo pericial contábil;

(f) Transcrição e resposta aos quesitos: para o parecer pericial contábil, onde houver divergência, transcrição dos quesitos, respostas formuladas pelo peritocontador e as respostas e comentários do perito-contador assistente;

(g) Conclusão;

(h) Anexos;

(i) Apêndices;

(j) Assinatura do perito: fará constar sua categoria profissional de contador e o seu número de registro em Conselho Regional de Contabilidade, comprovada mediante 
Declaração de Habilitação Profissional - DHP. É permitida a utilização da certificação digital, em consonância com a legislação vigente e as normas estabelecidas pela Infra-Estrutura de Chaves Públicas Brasileiras - ICP-Brasil.

Segundo Ornelas (2000, p.93) apud Zanna (2011, pp. 282-284), afirma que, "a estrutura adequada dos laudos depende do tipo de causa. Ele apresenta três estruturas, algo diferente entre si, segundo os três tipos de enfoque por ele adotados. Cita como exemplo os seguintes tipos de estrutura:

1. Para os laudos que demanda exames, vistorias, indagações e investigações contábeis:

1.Das considerações preliminares: a) aspectos gerais dos autos; b) diligências; c) procedimentos técnicos adotados; d) responsabilidade profissional;

2. Dos quesitos: a) do magistrado; b) do autor; c) do réu;

3. Das considerações finais:

4. Do encerramento;

Anexos;

Documentos;

a) Para os laudos que demandam arbitramento e avaliação:

1. Das considerações preliminares: a) aspectos gerais dos autos; b) das diligências; c) procedimentos técnicos adotados; d) da responsabilidade profissional;

2. Do arbitramento: a) das premissas adotadas; b) dos critérios adotados; c) da demonstração dos cálculos; d) da fixação dos valores arbitrados;

3. Do encerramento:

Anexos:

Documentos;

b) Para os laudos relacionados à apuração de haveres, como acontece em casos de dissolução total ou parcial da sociedade, afastamento de sócio, concordata, falência e casos assemelhados:

1. Das considerações preliminares: a) aspectos gerais dos autos; b) das diligências; c) da responsabilidade profissional;

2. Da apuração de haveres: a) das demonstrações contábeis especiais; b) dos ajustes contábeis; c) dos critérios e procedimentos avaliatórios; d) do balanço de determinação; f) dos haveres apurados;

4. Do encerramento:

Anexos:

Documentos.

No entendimento de Morais \& França (2000, p. 167) “o laudo pericial deve conter três partes principais e distintas, porém, todas comprometidas com o entendimento da totalidade da prova. São eles: (1) introdução, (2) respostas aos quesitos e (3) conclusões”.

Entende-se que além dos atributos citados pelos autores, o laudo ainda deve conter outros, de igual importância, como linguagem do idioma pátrio, devendo ser escrito na língua portuguesa, com clareza e objetividade. Também, deve se observar o conteúdo das 
informações precisas, completas, objetivas, imparcialidade e, acima de tudo, deve estar comprometido com a verdade que busca na causa.

Os anexos demonstrativos das análises e apurações efetuadas são partes integrantes do laudo pericial contábil e esses devem ser perfeitamente identificados, numerados e rubricados pelo perito, e sua juntada deve ser sequencial e de forma ordenada. Ao final, também numerados e identificados são juntados ao laudo os documentos que, dentro dos que lhe serviram de base e que o profissional considere indispensável á ilustração e bom entendimento do trabalho técnico. Entende-se que não se devem juntar sem motivo os documentos, principalmente quando em grande proporção.

Essas acuidades, por parte do perito, são relevantes e imprescindíveis, para evitar uma nova perícia, em função do que disciplina os artigos 437, 438 e 439 do Código de Processo Civil, a seguir transcritos:

\footnotetext{
Art. 437. O juiz poderá determinar, de ofício ou a requerimento da parte, a realização de nova perícia, quando a matéria não Ihe parecer suficientemente esclarecida.

Art. 438. A segunda perícia tem por objeto os mesmos fatos sobre que recaiu a primeira e destina-se a corrigir eventual omissão ou inexatidão dos resultados a que esta conduziu.

Art. 439. A segunda perícia rege-se pelas disposições estabelecidas para a primeira. Parágrafo único. A segunda perícia não substitui a primeira, cabendo ao juiz apreciar livremente o valor de uma e outra.
}

Assim, a responsabilidade do perito, em sua função de auxiliar da justiça, está evidenciada pela influência que o laudo pericial pode exercer sobre a sentença.

Portanto, como afirma Alberto (2002, p. 122), o perito deve “[...] agir conscientemente, conduzindo com rigor científico a realização do trabalho pericial, de maneira que seu resultado se afirme pela própria força de suas convicções e certezas", buscando encontrar a verdade demonstrável cientificamente.

Ressalta-se que diante da teoria apresentada o perito contador deve valer-se do rigor metodológico, observando-se os princípios éticos, a legislação pertinente à perícia e ao perito, além, da responsabilidade de sua profissão para fundamentar seu laudo, utilizando de todas as técnicas usuais e especiais, aplicáveis a situação para materializar a prova pericial, através do laudo pericial contábil de forma estruturada e conclusiva para que o nobre Juiz possa prolatar a respeitável sentença, com fundamento no laudo do perito contador. Importante, também, 
que o contador imponha a si mesmo uma frequente atualização, para conhecer e estudar as novas tecnologias para a busca da prova pericial contábeis.

Assim, a responsabilidade do perito, em sua função de auxiliar da justiça, está evidenciada pela influência que o laudo pericial pode exercer sobre uma sentença.

\section{Considerações finais}

A perícia contábil é um assunto relativamente complexo e controverso, pois a prova pericial contábil reflete em um trabalho realizado por profissional com grande conhecimento técnico na matéria de sua atuação, enquanto que decisões judiciais necessitam estar fundamentada em observações, fatos e ocorrências objetivas.

$\mathrm{O}$ confronto dos discentes à disciplina Perícia Contábil requer determinados conhecimentos acadêmicos, onde ele vai desenvolver habilidades e competências que os tornarão profissionais bem mais habilitados quando confrontados com a vivência prática. As ilustrações trazidas pelo professor, devidamente exemplificadas e ilustradas no transcorrer da disciplina, certamente irão contribuir para um melhor êxito na aprendizagem dos alunos e, no futuro, servirão para que possam exercer a função de Perito Contábil com mais confiança.

Pode-se citar algumas razões se ofertar a disciplina de Perícia Contábil nos cursos de graduação: o discente será logo de início exposto a várias realidades periciais ao longo do curso, o que irá permitir que possa estabelecer as devidas relações, importantes e necessárias para a compreensão do que seja uma Perícia Contábil; Em geral, alguns alunos já atuam profissionalmente, o que potencializa a motivação para a disciplina.

Espera-se que este estudo aporte subsídios para que as universidades, possam compreender a importância social da disciplina Perícia Contábil e assim, possam ajudar a melhorar as condições de ensino da dos cursos de contabilidade de uma maneira geral.

É possível que futuros estudos sobre esta temática possam ajudar a promover uma maior integração entre os assuntos tratados na sala de aula e a realidade objetiva da Perícia Contábil. 


\section{Referências}

ALBERTO, V. L. P. Perícia contábil: normas brasileiras de perícia contábil comentadas (NBC. T.13 e NBC.P.2), aspectos legais, civis e criminais, casos práticos de perícia contábil das áreas cível e trabalhista (instrução e liquidação), honorários periciais. ( $3^{\mathrm{a}}$ ed.). São Paulo: Atlas, 2002;

AGUIAR, J. L. Análise das demonstrações financeiras: vertical, horizontal e índices. Goiânia. Kelps, 2008;

Perícia judicial: planejamento de honorários, laudos, artigos do Código de Processo Civil (CPC) e normas técnicas. Goiânia: Publik, 2010;

BRASIL. Decreto-Lei $n^{o}$ 9.295/46, de 27 de maio de 1946. Disponível em: http://www.planalto.gov.br/ccivil_03/Decreto-Lei/De19295.htm. <Acessado em: 02 de dezembro de 2011>;

Código de Processo Civil - CPC, Lei $n^{o}$ 5.869/73. Disponível em: https://www2.camara.leg.br/legin/fed/lei/1970-1979/lei-5869-11-janeiro-1973-357991publicacaooriginal-1-pl.html. <Acessado em: 02 de dezembro de 2011>;

- Decreto-Lei $n^{o} \quad 9.295 / 46$. Disponível em: https://cfc.org.br/wpcontent/uploads/2015/12/lei1249.pdf. <Acessado em: 02 de dezembro de 2011>;

CONSELHO NACIONAL DE EDUCAÇÃO. CÂMARA DE EDUCAÇÃO SUPERIOR. Resolução CNE/CES 10, de 16 de Dezembro de $2004 . \quad$ Disponível em: http://portal.mec.gov.br/cne/arquivos/pdf/rces10_04.pdf. <Acessado em: 02 de dezembro de 2011>;

CONSELHO FEDERAL DE CONTABILIDADE. Resolução CFC $n^{\circ}$ 1244/2009 - Aprova a NBC PP 01 - Perito Contábil.Disponível em < http://www.cfc.org.br/sisweb/sre/detalhes_ sre.aspx?Codigo=2009/001244>. <Acessado em: 02 de dezembro de 2011>;

. Resolução $C F C n^{\circ}$ 1.243/09. aprova a NBC TP 01 - Perícia Contábil. <Acessado em: 02 de dezembro de 2011>;

CREPALDI, S. P. Contabilidade gerencial: teoria e prática. São Paulo: Atlas, 2004;

FIKER, J. Linguagem do laudo pericial: Técnicas de comunicação e persuasão. São Paulo: Leud, 2005;

HOOG, W.A.Z. Prova Pericial Contábil: Fundamentos práticos e fundamentais. (5a. ed.). Juruá, 2007;

Prova Pericial Contábil: Fundamentos práticos e fundamentais. (6ª ed.). Juruá, 2008;

IUDÍCIBUS, S. \& MARION, J. C. Introdução à teoria da contabilidade: para o nível de graduação. (2a. ed.). São Paulo: Atlas, 2000;

JESUS, F. Perícia e investigação de fraude: Uma análise psicológica e operacional na evidenciação de fraude. Goiânia: AB, 2000;

256 Id on Line Rev. Mult. Psic. V.13, N. 45 SUPLEMENTO 1, p. 236-257, 2019 - ISSN 1981-1179 Edição eletrônica em http://idonline.emnuvens.com.br/id 
MARION, J. C. O ensino da contabilidade. 2 ed. São Paulo: Atlas, 2001.

MONTANDON, M.M. Avaliação de empresas em perícias judiciais contábeis: um estudo de caso. Dissertação (mestrado em ciências contábeis). Faculdade de Administração e Ciências Contábeis da Universidade Federal do Rio de Janeiro (UFRJ). Rio de Janeiro: Universidade Federal do Rio de Janeiro, 2006;

MORAIS, A.C. A busca da prova pericial contábil. Brasília: Ibracperícias, 2005;

MORAIS, A.C \& FRANÇA J.A. Perícia judicial e extrajudicial: uma abordagem conceitual e práticas. (2 ${ }^{\mathrm{a}}$. ed.). Brasília: Qualidade, 2000;

MOURA, Ril. Perícia Contábil: judicial e extrajudicial.3.ed. Rio de Janeiro: Freitas Bastos, 2010.

ORNELAS, M. M. G. Avaliação de sociedades: Apuração de haveres em processos judiciais. (2a. ed.). São Paulo: Atlas, 2003;

PAVÓN, A. D. Costos para gestión. (1ª ed.). Asunción: Imperio, 2004;

PEREZ JR. J. H \& BEGALLI, G. A. Elaboração das Demonstrações Contábeis. (2ª . ed.). São Paulo: Atlas, 1999;

PIRES, M. A. A. Laudo pericial contábil na decisão judicial: de acordo com o código civil, código de processo civil e as normas do conselho federal de contabilidade. ( ${ }^{\mathrm{a}}$. ed. atual e ver.). Curitiba Juruá, 2008;

O papel do laudo pericial contábil na decisão judicial. Dissertação de Mestrado (mestrado em contabilidade). Fundação Visconde de Cairu de Salvador Bahia. Salvador: outubro, 2005;

ROCHA, A. R. \& SANTOS, N. Manual de perícia contábil judicial. (3 $3^{\mathrm{a}}$ ed.). Goiânia: Conselho Regional de Contabilidade de Goiás, 2004;

SÁ, A. L. Perícia Contábil. (7ª ed.). São Paulo: Atlas, 2005;

SANTOS, J. L; SCHMIDT, P \& GOMES, J. M. M. Fundamentos da perícia contábil. São Paulo: Atlas, 2006;

ZANNA, R. D. Prática de perícia contábil. (2ª ed. rev. e Ampl.). São Paulo: IOB, 2011.

\section{Como citar este artigo (Formato ABNT):}

AGUIAR, João Luis; GONZÁLEZ, Daniel González. Educação em Perícia Contábil: Importância da Disciplina para o Curso de Contabilidade. Id on Line Rev.Mult. Psic., 2019, vol.13, n.45 SUPLEMENTO 1, p. 236-257. ISSN: 1981-1179.

Recebido: 13/05/2019

Aceito 18/05/2019

257 Id on Line Rev. Mult. Psic. V.13, N. 45 SUPLEMENTO 1, p. 236-257, 2019 - ISSN 1981-1179

Edição eletrônica em http://idonline.emnuvens.com.br/id 